\title{
ОБЛІК І АУДИТ ДОХОДІВ І ВИТРАТ ПІДПРИЕМСТВ В УМОВАХ ГЛОБАЛЬНИХ ВИКЛИКІВ
}

DOI: $10.32620 /$ cher.2020.4.09

Постановка проблеми. В умовах глобальних викликів діяльність підприємств здійснюється в умовах динамічного, важкопередбачуваного зовнішнього середовища, тому для забезпечення умов беззбиткової діяльності та підвищення рентабельності від підприємства вимагається модифікація існуючої системи управління, ефективність якої, в свою чергу, визначається рівнем обліковоаналітичного забезпечення системи витрат і доходів за видами діяльності підприємства, тому удосконалення обліку і аудиту доходів і витрат торговельних підприємств $є$ актуальним, особливо в умовах сучасних глобальних викликів. Метою статті $\epsilon$ удосконалення процедури обліку і аудиту доходів і витрат торговельних підприємств. Предмет дослідження - система обліку доходів і витрат підприємства. Методи, використані в дослідженні: аналіз, синтез, абстрактно-логічний; історичний, порівняльний і статистичний, узагальнення та групування; системно-структурний та функціональний. Гіпотеза дослідження. Діюча система обліку і процедура аудиту має бути модифікована відповідно до реалій діяльності торговельних підприємств в умовах сучасних глобальних викликів. Виклад основного матеріалу. Проаналізовано організаційні положення обліку витрат і доходів за видами діяльності та виявлено недоліки в існуючій практиці їх облікового відображення на прикладі одного $з$ торговельних підприємств - ТОВ «ЖАККАРД», визначено заходи $з$ покращення обліку витрат і доходів за видами діяльності. Розглянуто завдання аудиту витрат та доходів за видами діяльності підприємства, план аудиту та запропоновано тестові питання аудитора для перевірки правильності організації обліку витрат і доходів та результати для торгівельного підприємства. Практичне значення дослідження полягає у можливості застосування наданих пропозицій щодо вдосконалення обліку й аудиту витрат і доходів у діяльності торговельного підприємства. Висновки дослідження. Проведене дослідження дозволить підвищити ефективніть процедури обліку і аудиту витрат та доходів, а своєчасне та правильне ведення бухгалтерського обліку сприятиме прийняттю ефективніших управлінських рішень у процесі формування чистого доходу, а використання планів аудиту витрат і доходів дозволить точніше виявити недоліки в організації й веденні бухгалтерського обліку на підприємстві.

Ключові слова:

аудит доходів і витрат, глобальні виклики, облік доходів і витрат, процедура, торговельні підприємтва.

\section{ACCOUNTING AND AUDIT OF ENTERPRISES REVENUES AND EXPENSES IN CONDITIONS OF GLOBAL CHALLENGES}

Formulation of the problem. In the context of global challenges, enterprises operate in a dynamic, unpredictable external environment, so to ensure break-even conditions and increase profitability of the company requires a modification of the existing management system, the effectiveness of which, in turn, is

${ }^{1}$ Татар Марина Сергіївна, канд. екон. наук, доцент кафедри фінансів, обліку і оподаткування, Національний аерокосмічний університет ім. М. Є. Жуковського «Харківський авіаційний інститут», м. Харків, Україна.

Tatar Maryna, Ph.D in Economics, Associate professor of the Finance, Accounting and Taxation Department, National Aerospase University «Kharkiv Aviation Institute», Kharkiv, Ukraine.

ORCID ID: 0000-0002-1111-7103

e-mail: marina.sergeevna.tatar@gmail.com

${ }^{2}$ Ванярха Ганна Михайлівна, студент спеціальності 071 «Облік і оподаткування» Національний аерокосмічний університет ім. М. Є. Жуковського «Харківський авіаційний інститут», м. Харків, Україна.

Vaniarkha Hanna, student majoring in 071 "Accounting and Taxation", National Aerospase University «Kharkiv Aviation Institute», Kharkiv, Ukraine.

ORCID ID: 0000-0003-4511-2113

e-mail: tiannacity@gmail.com 
determined by the level of accounting and analytical costs. types of activity of the enterprise, therefore improvement of the account and audit of incomes and expenses of the trading enterprises is actual, especially in the conditions of modern global challenges. The aim of the research is improvement the procedure for accounting and auditing revenues and expenses of commercial enterprises. The subject of the research is the system of accounting for enterprise income and expenses. The methods of the research: analysis, synthesis, abstract logic; historical, comparative and statistical, generalization and grouping; system-structural and functional. The hypothesis of the research. The current accounting system and audit procedure should be modified in accordance with the realities of existing trading companies in the conditions of their activity during modern global challenges. The statement of basic materials. The organizational provisions of accounting for costs and revenues by type of activity are analyzed and shortcomings in the existing practice of their accounting are identified on the example of one of the trading companies - JACQUARD LLC, measures to improve the accounting of costs and revenues by type of activity are identified. The task of auditing costs and revenues by type of activity of the enterprise, the audit plan and test questions of the auditor to verify the correctness of the organization of cost and income accounting and the results for the trading company. The originality and practical significance of the research lies in the possibility of applying the proposals for improvement the accounting and audit of costs and revenues by type of enterprise activity. Conclusions and perspectives of further research. The research will improve the efficiency of accounting and auditing of costs and revenues, and timely and proper accounting will facilitate more effective management decisions in the process of generating net income, and the use of audit plans of costs and revenues will more accurately identify deficiencies in the organization and accounting of the enterprise .

Key words:

revenue and expenditure audit, global challenges, income and expenditure accounting, procedure, trade enterprises

\section{УЧЕТ И АУДИТ ДОХОДОВ И РАСХОДОВ ПРЕДПРИЯТИЙ В УСЛОВИЯХ ГЛОБАЛЬНЫХ ВЫЗОВОВ}

Постановка проблемы. В условиях глобальных вызовов деятельность предприятий осуществляется в условиях динамичной, труднопредсказуемой внешней среды, поэтому для обеспечения условий безубыточной деятельности и повышения рентабельности от предприятия требуется модификация существующей системы управления, эффективность которой, в свою очередь, определяется уровнем учетно-аналитического обеспечения системы расходов и доходов по видами деятельности предприятия, поэтому усовершенствование учета и аудита доходов и расходов торговых предприятий является актуальным, особенно в условиях современных глобальных вызовов. Целью статьи является усовершенствование процедуры учета и аудита доходов и расходов торговых предприятий. Предмет исследования - система учета доходов и расходов предприятия. Meтоды, использованные в исследовании: анализ, синтез, абстрактно-логический; исторический, сравнительный и статистический, обобщения и группировки; системно-структурный и функциональный. Гипотеза исследования. Действующая система учета и процедура аудита должна быть модифицирована в соответствии с реалиями работы торговых предприятий в условиях современных глобальных вызовов. Изложение основного материала. Проанализированы организационные положения учета затрат и доходов по видам деятельности и выявлены недостатки в существующей практике их учетного отображения на примере одного из торговых предприятий ООО «ЖАККАРД», определены меры по улучшению учета расходов и доходов по видам деятельности. Рассмотрены задачи аудита расходов и доходов по видам деятельности предприятия, предложен план аудита и тестовые вопросы аудитора для проверки правильности организации учета затрат и доходов и результаты для торгового предприятия. Практическое значение исследования заключается в возможности применения предоставленных предложений по усовершенствованию учета и аудита расходов и доходов в деятельности предприятия. Выводы исследования. Проведенное исследование позволит повысить эффективность процедуры учета и аудита расходов и доходов, а своевременное и правильное ведение бухгалтерского учета будет способствовать принятию эффективных управленческих решений в процессе формирования чистого дохода, использование планов аудита расходов и доходов позволит точнее выявить недостатки в организации и ведении бухгалтерского учета на предприятии .

Ключевые слова:

аудит доходов и расходов, глобальные вызовы, учет доходов и расходов, процедура, 
Постановка проблеми. В сучасних умовах глобальних викликів постає необхідність до впровадження нетрадиційних систем одержання інформації про витрати та доходи, застосування нових підходів до калькулювання собівартості, підрахунку фінансових результатів, методів аналізу витрат та доходів і прийняття на цій основі раціональних управлінських рішень, адекватних ситуації, яка склалася внаслідок глобальних викликів. В умовах глобальних викликів діяльність підприємств здійснюється в умовах динамічного, інколи доволі важкопередбачуваного зовнішнього середовища, що передбачає розірвання вже усталених взаємозв'язків суб'єктів господарювання, зміну форматів взаємодії суб'єктів господарювання між собою, 3 органами державної влади, іншими інституціями, нестабільність правового поля тощо. У такій ситуації для забезпечення умов беззбиткової діяльності та підвищення рентабельності від підприємства вимагається модифікація існуючої системи управління. Водночас, ефективність управління визначається рівнем обліково-аналітичного забезпечення системи витрат і доходів за видами діяльності підприємства.

Аналіз останніх досліджень i публікацій. Окремі питання теорії та методики бухгалтерського обліку доходів i витрат знайшли відображення у працях науковців, таких як В.С Бєлозерцев [1], В.I.

Блонська [2], В. А. Дерій [3], Т.П. Добрунік [4], С.В. Князь, Н.П. Яворська [5] тощо. Однак ряд проблем, пов'язаних із відображенням у бухгалтерському обліку витрат i доходів за видами діяльності підприємства та їх оцінкою залишаються недостатньо розробленими i вимагають вирішення 3 урахуванням національних особливостей ведення бухгалтерського обліку.

Метою статті с удосконалення процедури обліку і аудиту доходів і витрат торговельних підприємств.

Виклад основного матеріалу дослідження. Під час загальної оцінки діяльності підприємства аналіз доходів основної діяльності має особливо важливе значення, оскільки доходи мають прямий вплив на формування загального фінансового результату підприємства. Проведемо аналіз доходів основної діяльності торговельного підприємства ТОВ «ЖАККАРД», яке здійснює оптову торгівлю одягом і взуттям, а також здійснення різних видів торгівельної діяльності (в тому числі оптової, роздрібної, комісійної торгівлі) з метою пошуку шляхів збільшення доходів та скорочення витрат підприємства.

Проаналізуємо структуру доходів ТОВ «ЖАККАРД» за 2017-2019 рр. в табл. 1, визначивши питому вагу доходів від основної діяльності в їх загальному обсязі, а також абсолютне та відносне відхилення.

Т а б ли ц я 1

Структура доходів діяльності ТОВ «ЖАККАРД» за 2017- 2019 рр.

\begin{tabular}{|c|c|c|c|c|c|c|c|}
\hline \multirow[b]{2}{*}{ Статті доходів } & \multicolumn{2}{|c|}{2017 рік } & \multicolumn{2}{|c|}{2018 рік } & \multicolumn{2}{|c|}{2019 рік } & \multirow{2}{*}{$\begin{array}{c}\text { Абсолютне } \\
\text { відхилення, } \\
\text { тис. грн. }\end{array}$} \\
\hline & $\begin{array}{c}\text { Абс., тис. } \\
\text { грн }\end{array}$ & Відн.,\% & $\begin{array}{c}\text { Абс., тис. } \\
\text { грн }\end{array}$ & Відн., \% & $\begin{array}{c}\text { Абс., тис. } \\
\text { грн }\end{array}$ & Відн., \% & \\
\hline $\begin{array}{l}\text { Чистий дохід від } \\
\text { реалізації }\end{array}$ & 3332,3 & 100 & 5730,1 & 100 & 4751,2 & 99,9 & 1418,9 \\
\hline $\begin{array}{l}\text { Інші операційні } \\
\text { доходи }\end{array}$ & 0 & 0 & 0 & 0 & 0,3 & 0,006 & 0,3 \\
\hline Інші доходи & 0 & 0 & 0 & 0 & 0 & 0 & 0 \\
\hline Разом доходи & 3332,3 & 100 & 5730,1 & 100 & 4751,5 & 100 & 1419,2 \\
\hline $\begin{array}{l}\text { Фінансовий } \\
\text { результат }\end{array}$ & 99,1 & - & 116,1 & - & $-371,1$ & - & $-371,1$ \\
\hline
\end{tabular}

Джерело: розроблено авторами

Основна діяльність ТОВ «ЖАККАРД» забезпечує найбільшу частину його доходів, частка інших операційних доходів в загальній їх кількості не перевищувала $0,006 \%$ у 2019 році та становила 0 у 2017, 2018 роках. Фінансовий результат від операційної діяль- ності у 2019 р. суттєво змінився і становив 371тис. грн., в порівнянні з 2018 роком, коли підприємство мало прибуток у розмірі 116,1 тис.грн. Дохід від реалізації готової продукції забезпечує 99,9\% усіх доходів підприємства. За звітний період 2019 р. його величина 
зменшилася, що вплинуло на зменшення фінансового результату на 470,2 тис. грн., що $\epsilon$ негативною тенденцією для підприємства.

Потребує впорядкування бухгалтерський облік операцій щодо продажу товарів 3 можливістю аналітичної й синтетичної деталізації для раціональної організації їх контролю та прийняття обгрунтованих управлінських рішень. Оскільки метою ведення бухгалтерського обліку операцій 3 продажу товарів є надання користувачам інформації про результати діяльності торговельного підприємства для прийняття рішень, де- талізацію рахунків варто здійснювати, максимально відображаючи інформаційну систему управління продажами товарів [1].

Якщо підприємство самостійно приймає рішення щодо ведення аналітичного обліку та відкриття рахунків третього і нижчих порядків, з метою деталізації інформації, доречно ввести до рахунку 70.2 «Дохід від реалізації товарів», та до рахунку 74 «Вирахування 3 доходу» рахунки третього порядку - субрахунки й аналітичні рахунки внутрішньогосподарського (управлінського) обліку (табл. 2) [2].

Т а б ли ц я 2

Синтетичні та аналітичні рахунки доходу

\begin{tabular}{|c|c|}
\hline $\begin{array}{c}\text { Синтетичні рахунки, суб- } \\
\text { рахунки (рахунки першо- } \\
\text { го, другого порядків) }\end{array}$ & Аналітичні рахунки (субрахунки третього порядку) \\
\hline \multirow{5}{*}{$\begin{array}{l}70.2 \text { «Дохід від реалізації } \\
\text { товарів» }\end{array}$} & 70.21 «Дохід від реалізації товарів» \\
\hline & 70.22«Дохід від реалізації товарів за дисконтними картками» \\
\hline & 70.23«Дохід від реалізації товарів зі знижками» \\
\hline & 70.24 «Дохід від реалізації товарів у період розпродажу» \\
\hline & $\begin{array}{l}70.25 \text { «Дохід від реалізації товарів за іншими заходами впливу на } \\
\text { обсяги продажу товарів» }\end{array}$ \\
\hline \multirow{3}{*}{$\begin{array}{l}70.4 \text { «Вирахування } 3 \text { до- } \\
\text { ходу» }\end{array}$} & 70.41 «Вирахування з доходу за товари, повернені покупцями» \\
\hline & 70.42 «Сума знижок, наданих покупцям» \\
\hline & 70.43 «Інші вирахування з доходу» \\
\hline
\end{tabular}

За допомогою цих синтетичних рахунків 3'являється можливість виділити з усього доходу торговельного підприємства дохід від реалізації товарів за методами активізації продажу товарів, що дозволяє проводити поглиблений аналіз продажів, вирішувати питання доцільності застосування того чи іншого маркетингового інструмента. Це сприятиме прийняттю ефективніших управлінських рішень у процесі формування чистого доходу підприємства [3].
Розглянемо господарські операції 3 відображення доходу від реалізації виконаних робіт ТОВ «ЖАККАРД», здійснені на основі видаткових накладних які наведено в табл. 3 , та визначимо фінансовий результат за 2018 рік. Пд час глобальних викликів та дисбалансів торгівельним підприємствам можуть стикатися 3 неможливістю визначити величину або немає гарантії в оплаті продукції, тому пропонується використання методів відображення доходу в умовах ризику несплати коштів за продукцію (табл. 4).

Т а б ли и я 3

Відображення в обліку доходів від реалізації товарів ТОВ «ЖАККАРД»

\begin{tabular}{|c|c|c|c|c|}
\hline № & Зміст операції & Дебет & Кредит & Сума, грн \\
\hline 1 & $\begin{array}{l}\text { Підписано видаткову } \\
\text { накладну }\end{array}$ & 36 & 70.1 & 6876064,26 \\
\hline 2 & Відображено ПДВ & 70.1 & 64.3 & 1146010,71 \\
\hline 3 & $\begin{array}{l}\text { Відображено собівартість } \\
\text { товарів }\end{array}$ & 79 & 28 & 5230355,00 \\
\hline 4 & Відображено чистий дохід & 70.1 & 79 & 5730053,55 \\
\hline \multirow{6}{*}{5} & \multirow{5}{*}{ Інші операційні витрати } & \multirow{5}{*}{79} & 81 & 163503,68 \\
\hline & & & 82 & 35970,82 \\
\hline & & & 83 & 50498,39 \\
\hline & & & 84 & 99549,97 \\
\hline & & & 85 & 34056,98 \\
\hline & \multicolumn{3}{|c|}{ Фінансовий результат (рахунок 44) } & 116118,71 \\
\hline
\end{tabular}

Джерело: розроблено авторами на підставі $[6,7,8]$ 
Т а б л и ц я 4

Методи відображення доходу в умовах ризику несплати коштів за продукцію

\begin{tabular}{|c|c|c|}
\hline Методи & Визнання доходу & Характеристика \\
\hline $\begin{array}{l}\text { Метод продажу } \\
\text { в розстрочку }\end{array}$ & $\begin{array}{l}\text { Визнається саме в той } \\
\text { період, в якому надійшли } \\
\text { кошти, а не в момент ре- } \\
\text { алізації. }\end{array}$ & $\begin{array}{l}\text { При відвантаженні продукції списується повна } \\
\text { вартість } 3 \text { балансу, на суму якої визнається } \\
\text { дебіторська заборгованість. Разом } 3 \text { тим, на суму } \\
\text { нарахованої націнки в обліку відображають } \\
\text { відстрочений дохід. А вже при надходження } \\
\text { коштів від покупця визнається дохід у сумі пла- } \\
\text { тежу, який надійшов, і пропорційно з ним спи- } \\
\text { сується націнка }\end{array}$ \\
\hline $\begin{array}{l}\text { Метод відшко- } \\
\text { дування витрат }\end{array}$ & $\begin{array}{l}\text { Визнається в момент, коли } \\
\text { надходження } \text { від покупця } \\
\text { повністю } \\
\text { собівартість відвантажених } \\
\text { товарів. }\end{array}$ & $\begin{array}{l}\text { Характеризується тим, що перш ніж відобразити } \\
\text { прибуток, компенсуються всі затрати. Відстроче- } \\
\text { ний прибуток визнають лише після сплати всіх } \\
\text { платежів. Якщо вони надійшли не в повній мірі, } \\
\text { визнаний прибуток буде менше відстроченого на } \\
\text { суму платежів, які не було виплачено. Метод за- } \\
\text { стосовують для операцій, з високим рівнем } \\
\text { ризику. }\end{array}$ \\
\hline
\end{tabular}

Джерело: складено авторами на підставі [3]

В умовах глобальних викликів і дисбалансів особливо необхідно звертати увагу на аудиторське підтвердження достовірності даних про доходи i витрати, процеси їх формування, не ігноруючи реалізацію аналітичних процедур аудиту.

Аудит витрат і доходів від операційної діяльності представляється у вигляді певної послідовності етапів, кожен 3 яких передбачає сукупність здійснюваних аудитором процедур. При цьому думки авторів щодо черговості етапів та їх змісту нерідко відрізняються. Проте в будь-якому випадку дії, що здійснює аудитор під час перевірки, свідчать про необхідність інформації, яка дозволяє зробити висновки та висловити думку щодо достовірності звітності. У зв'язку 3 цим, важливими $є$ точність, достовірність, надійність та своєчасність такої інформації [4].

Отже, організація і методика аудиту витрат і доходів від діяльності визначається, передусім, належним інформаційним забезпеченням аудитора, що є досить актуальним, адже інформація про витрати і доходи операційної діяльності $\epsilon$ основою самого аудиторського процесу. Зростання обсягів інформації потребує від аудитора певної її систематизації і класифікації, оскільки без такого підходу важко зібрати необхідні аудиторські докази, правильно оцінити господарські явища, факти, процеси виробництва [5]. Завдання аудиту витрат та доходів за видами діяльності підприємства наведено в табл. 5.

Стосовно аудиту доходів і витрат, крім загальноприйнятої методики досліджень при його проведенні слід виділити аналітичні процедури для об' єктивного оцінювання поведінки доходів і витрат у конкурентному середовищі та суб'єктивні впливи кон'юнктури стратегічного і тактичного менеджменту, паритетність інтересів у визнанні кінцевого фінансового результату. Особливість аналітичних процедур обумовлює:

- визнання доцільності щодо повноти формування доходу та визнання витрат відповідно до кон'юнктури ринку і економічного потенціалу господарюючого суб'єкта;

- обгрунтованість структури формування доходу за видами діяльності, відображення витрат за порядком їх покриття;

- інтенсивність і якість формування доходів відповідно до зміни кон'юнктури зовнішнього середовища;

- раціоналізація витрат і повнота використання сприятливого середовища;

- розмежування дії об'єктивних i суб'єктивних чинників формування доходів i витрат;

- вимірювання ділової активності та креативного менеджменту за центрами відповідальності тощо [6].

При здійсненні економічних процедур при аудиті витрат і доходів від діяльності слід ї розмежувати за двома рівнями:

1) процедури першого рівня пов'язані із аналізом інформаційних ресурсів: від відображення даних у первинних документах до зведених показників фінансової і статистичної звітності. 
Завдання аудиту витрат та доходів за видами діяльності підприсмства

\begin{tabular}{l}
\hline Завдання аудиту витрат та доходів за видами діяльності підприємства: \\
- встановлення правильності документального оформлення накопичення та списання витрат, чи \\
дійсно всі отримані доходи відображені на рахунках бухгалтерського обліку та у фінансовій \\
звітності; \\
- перевірка правильності ведення обліку фактичних витрат та наступного включення їх до \\
собівартості продукції (робіт, послуг) відповідно до прийнятого на підприємстві методу обліку \\
витрат та калькулювання правильності і точності визначення величини фінансових результатів \\
від операційної діяльності у відповідності з прийнятою на підприємстві обліковою політикою; \\
- правильність оцінки в бухгалтерському обліку доходів (в сумі справедливої вартості активів, \\
що отримані або підлягають отриманню) і витрат (згідно з П(С)БО 16) для визначення фінансо- \\
вих результатів; \\
- підтвердження обгрунтованості обраного методу калькулювання; \\
- підтвердження правильності методу розподілу непрямих витрат, що використовуються, і за- \\
кріплений в наказі про облікову політику; \\
\hline - перевірка правильності та обгрунтованості планування розміру прямих витрат, які включають- \\
ся до собівартості продукції (робіт, послуг), та визначення кошторисних ставок розподілу \\
накладних витрат; \\
- підтвердження законності і правильності відображення на рахунках бухгалтерського обліку \\
витрат діяльності, щодо визначення і відображення операцій, що призвели до виникнення \\
фінансових результатів; \\
\hline - перевірка повноти, правильності та достовірності відображення інформації про витрати \\
підприємства в звітності - чи не завищило підприємство доходи і не занизило витрати. \\
\hline
\end{tabular}

Джерело: розроблено авторами

Тут пріоритетним $€$ застосування логіко-економічних прийомів аналізу, які підтверджують аргументованість у кваліфікації доходів і витрат за видами діяльності та їх зведення за аналітичними ознаками, балансову узгодженість джерел формування доходів і витрат та кінцевих результатів їх впливу на стан економічної системи загалом, обгрунтованість вибору варіантів їх формування за критеріями доречності тощо;

2) процедури другого рівня пов'язані 3 оцінками та діагностикою величини та зміни доходів і витрат відносно до параметрів управління ними (планування, нормування, коректування і т. п.) [5].

Отже, проведення аудиту витрат і доходів від діяльності повинно складатися 3 декількох етапів:

- ознайомлювальний етап (загальне ознайомлення 3 веденням бухгалтерського обліку витрат на виробництво, 3 нормативними документами підприємства);

- основний етап (безпосереднє проведення перевірки);

- заключний етап (складання та надання аудиторського висновку, оформлення інших документів).

У подальшому основними методами, які необхідно використовувати при аудиті витрат і доходів діяльності є: опитування, фактична перевірка, порівняння, перерахунок, документальна перевірка, вибіркове дослідження.

Отримана таким чином інформація на початку перевірки дасть змогу отримати загальне уявлення про організацію обліку витрат i доходів діяльності на даному підприємстві.

Під час фактичної перевірки варто застосовувати тестові питання, відповіді на які допоможуть встановити правомірність відображення в обліку витрат та доходів операційної діяльності (табл. 6).

За випробуваним тестуванням на підприємстві отримано результат: 1 відповідає вимогам, 0 - не відповідає.

За результатами тестування системи внутрішнього контролю і бухгалтерського обліку витрат і доходів діяльності підприємства виявлено:

- визнання доходів і витрат відповідає П(с)БО № 15 і П(с)БО 16;

- не було виявлено випадки реалізації продукції без документів на відвантаження;

- не було у звітному періоді зміни в класифікації витрат на постійні та змінні, прямі та непрямі; 


\section{Тестові питання аудитора для перевірки правильності організації обліку витрат і доходів та результати для торгівельного підприємства}

\begin{tabular}{|c|c|c|}
\hline \multirow[t]{2}{*}{$\begin{array}{c}\text { Рекомендовані питання аудитора для тестування системи } \\
\text { внутрішнього контролю і бухгалтерського обліку витрат і } \\
\text { доходів діяльності }\end{array}$} & \multicolumn{2}{|c|}{$\begin{array}{c}\text { Результат тестування системи } \\
\text { внутрішнього контролю і бухгалтер- } \\
\text { ського обліку витрат і доходів } \\
\text { діяльності на ТОВ «ЖАККАРД» }\end{array}$} \\
\hline & Так & $\mathrm{Hi}$ \\
\hline $\begin{array}{l}\text { 1. Чи відповідає визнання доходів П(с)БО № } 15 \text { і витрат } \\
\text { П(с)БО } 16 ?\end{array}$ & 1 & \\
\hline $\begin{array}{l}\text { 2. Особи, які дають дозвіл на реалізацію продукції (робіт, } \\
\text { послуг): керівник? }\end{array}$ & 1 & \\
\hline $\begin{array}{l}\text { 3. Особи, які розробляють і затверджують цінову політику: } \\
\text { керівник? }\end{array}$ & 1 & \\
\hline $\begin{array}{l}\text { 4. Чи були виявлені випадки реалізації продукції без доку- } \\
\text { ментів на відвантаження? }\end{array}$ & & 0 \\
\hline $\begin{array}{l}\text { 5. Чи були у звітному періоді зміни в класифікації витрат } \\
\text { на постійні та змінні? }\end{array}$ & & 0 \\
\hline $\begin{array}{l}\text { 6. Чи були у звітному періоді зміни в класифікації витрат } \\
\text { на прямі і непрямі? }\end{array}$ & & 0 \\
\hline $\begin{array}{l}\text { 7. Чи ведеться окремо облік різних видів доходів: відо- } \\
\text { мості; картки; інше? }\end{array}$ & & 0 \\
\hline $\begin{array}{l}\text { 8. Чи є відповідальні особи за повноту і своєчасність } \\
\text { відвантаження товарів (робіт, послуг)? }\end{array}$ & 1 & \\
\hline $\begin{array}{l}\text { 9. Чи затверджені на підприємстві методичні рекомендації } \\
\text { щодо розрахунку собівартості реалізованої продукції }\end{array}$ & & 0 \\
\hline $\begin{array}{l}\text { 10. Чи звіряються рахунки-фактури із затвердженими за- } \\
\text { мовленнями на продаж і документами на відвантаження } \\
\text { продукції? }\end{array}$ & 1 & \\
\hline $\begin{array}{l}\text { 11. Чи здійснюються перевірки визнання доходів згідно } 3 \\
\text { П(с)БО? }\end{array}$ & 1 & \\
\hline $\begin{array}{l}\text { 12. Чи перевірялися критерії визнання доходів згідно з } \\
\text { класифікацією доходів? }\end{array}$ & 1 & \\
\hline $\begin{array}{l}\text { 13. Чи узгоджується з головним бухгалтером реалізація } \\
\text { продукції (робіт, послуг) боржникам? }\end{array}$ & & 0 \\
\hline $\begin{array}{l}\text { 14. Чи укладаються договори з кожним покупцем на } \\
\text { кожний вид реалізації робіт (послуг)? }\end{array}$ & 1 & \\
\hline
\end{tabular}

Джерело: розроблено авторами на підставі [3]

- не затверджені на підприємстві методичні рекомендації щодо розрахунку собівартості реалізованої продукції;

- рахунки-фактури звіряються із затвердженими замовленнями на продаж і документами на відвантаження продукції

- перевірялися критерії визнання доходів згідно з класифікацією доходів;

- не узгоджується 3 головним бухгалтером реалізація продукції (робіт, послуг) боржникам;

- укладаються договори 3 кожним покупцем на кожний вид реалізації робіт (послуг).

При аудиті витрат на виробництво встановлюється наявність калькуляцій (пла- нових і звітних). Необхідно перевірити правильність складання звітів по собівартості продукції, записи в бухгалтерських документах для виявлення необгрунтованих списань різних витрат на виробництво. При проведенні перевірки аудитору потрібно перевірити дотримання встановленого порядку обліку і калькулювання собівартості продукції за окремими виробами [5].

На підготовчому етапі аудиту доходів від основної діяльності слід передбачити наступні питання для перевірки (табл. 8).

Для забезпечення ефективності аудиторської перевірки необхідно дослідити порядок відображення доходів в облікових регістрах і фінансовій звітності. 
Т а б л и ц я 7

План аудиту витрат

\begin{tabular}{|c|c|c|c|c|}
\hline № 3/ח & Перелік аудиторських процедур & Виконавець & $\begin{array}{c}\text { Період } \\
\text { перевірки }\end{array}$ & Примітки \\
\hline 1 & 2 & 3 & 4 & 5 \\
\hline \multicolumn{5}{|c|}{ I. Адміністративні витрати (рахунок 83) } \\
\hline 1. & $\begin{array}{l}\text { Перевірка обгрунтованості включення витрат до скла- } \\
\text { ду адміністративних }\end{array}$ & & & \\
\hline 2. & $\begin{array}{l}\text { Наведення складу витрат за статтями згідно із застосо- } \\
\text { вуваною підприємством класифікацією }\end{array}$ & & & \\
\hline 3. & $\begin{array}{llrr}\text { Перевірка обгрунтованості } & \text { віднесення } & \text { до складу } \\
\text { адміністративних витрат } & \text { податків, } \\
\text { обов'язкових платежів } & & & \\
\text { збові та }\end{array}$ & & & \\
\hline 4. & $\begin{array}{l}\text { Складання переліку видів і сум податків, віднесених на } \\
\text { адміністративні витрати }\end{array}$ & & & \\
\hline 5. & $\begin{array}{l}\text { Перевірка наявності й повноти оформлення доку- } \\
\text { ментів, що підтверджують витрати }\end{array}$ & & & \\
\hline \multicolumn{5}{|c|}{ II. Витрати на страхування (рахунок 82) } \\
\hline 1. & $\begin{array}{l}\text { Перевірка обгрунтованості включення витрат до скла- } \\
\text { ду витрат на страхування }\end{array}$ & & & \\
\hline 2. & $\begin{array}{l}\text { Наведення складу витрат за центрами виникнення вит- } \\
\text { рат згідно із застосовуваною підприємством кла- } \\
\text { сифікацією }\end{array}$ & & & \\
\hline 3. & $\begin{array}{l}\text { Перевірка наявності й повноти оформлення доку- } \\
\text { ментів, що підтверджують витрати }\end{array}$ & & & \\
\hline \multicolumn{5}{|c|}{ III. Інші операційні витрати (рахунок 84) } \\
\hline 1. & $\begin{array}{l}\text { Перевірка відповідності застосованого методу оцінки } \\
\text { запасів при реалізації обліковій політиці }\end{array}$ & & & \\
\hline 2. & $\begin{array}{l}\text { Перевірка правильності розрахунку резерву сумнівних } \\
\text { боргів }\end{array}$ & & & \\
\hline 3. & $\begin{array}{l}\text { Перевірка обгрунтованості списання на витрати по- } \\
\text { точної безнадійної заборгованості в сумі, що переви- } \\
\text { щує резерв сумнівних боргів }\end{array}$ & & & \\
\hline 4. & $\begin{array}{l}\text { Перевірка правильності відображення в обліку витрат } \\
\text { від знецінення, нестачі та псування запасів }\end{array}$ & & & \\
\hline 5. & $\begin{array}{l}\text { Перевірка наявності та повноти оформлення доку- } \\
\text { ментів, що підтверджують витрати }\end{array}$ & & & \\
\hline
\end{tabular}

Джерело: розроблено авторами

Т а б ли ц я 8

\section{План аудиту доходів від основної діяльності}

\begin{tabular}{|c|l|l|l|l|}
\hline № & \multicolumn{1}{|c|}{ Перелік аудиторських процедур } & Виконавець & $\begin{array}{c}\text { Період } \\
\text { перевірки }\end{array}$ & Примітки \\
\hline 1. & $\begin{array}{l}\text { Перевірка відповідності облікової політики щодо обліку } \\
\text { доходів нормам діючого законодавства }\end{array}$ & & \\
\hline 2. & $\begin{array}{l}\text { Перевірка правильності класифікації доходів за видами } \\
\text { діяльності і звітними періодами }\end{array}$ & & & \\
\hline 3. & Перевірка первинних документів з обліку доходів & & \\
\hline 4. & Перевірка визнання і розрахунку доходів від реалізації & & \\
\hline 5. & $\begin{array}{l}\text { Перевірка відповідності даних синтетичного і аналітичного } \\
\text { обліку за рахунками класу 7 }\end{array}$ & & \\
\hline 6. & Формування висновків за результатами аудиту & & \\
\hline
\end{tabular}

Джерело: розроблено авторами на підставі [5]

Наприклад, кредит рахунку 70 «Дохід від реалізації» за мінусом непрямих податків i зборів повинен відповідати рядку 2000 у Звіті про фінансові результат [6].

Висновки та перспективи подалыших досліджень. Отже, організація і методика аудиту витрат і доходів від діяльності визначається, передусім, належним інформаційним забезпеченням аудитора, що $є$ досить актуальним, адже інформація про витрати і доходи операційної діяльності $\epsilon$ основою самого аудиторського процесу. Зростання обсягів інформації потребує від аудитора певної іï систематизації і класифікації, оскільки без такого підходу важко 
зібрати необхідні аудиторські докази, правильно оцінити господарські явища, факти, процеси виробництва. Застосування синтетичних рахунків сприятиме прийняттю ефективніших управлінських рішень у процесі формування чистого доходу, а використання планів аудиту витрат і доходів дозволить точніше виявити недоліки в організації й веденні бухгалтерського обліку на підприємстві.

\section{Література}

1. Бєлозерцев В. С., Кузнецова О. М. Звіт про фінансові результати його сутність і значення в контексті національних та міжнародних стандартів бухгалтерського обліку. Глобальні та національні проблеми економіки. 2016. № 14. C. $902-904$.

2. Блонська В.I. Стратегія управління доходами торговельного підприємства в умовах розвитку ринкових відносин. Науковий вісник НЛТУ Украйни : зб. наук.- техн. пращь. 2008. Вип. 18.6. С. 117-123.

3. Дерій В. А. Витрати $i$ доходи підприємств у системі обліку та контролю: монографія. Тернопіль: ТНЕУ, «Економічна думка», 2009. 272 с.

4. Добрунік Т.П. Сучасна проблематика обліку фінансових результатів діяльності торговельних підприємств. Науковий вісник Ужгородського національного університету. Серія: Міжнародні економічні відносини та світове господарство. 2017. Вип. 13, ч. 1. С. 95-99.

5. Князь С.В., Залуцький В.П., Яворська Н. П. Проблеми обліку доходів та витрат торговельних підприємств. Ефективна економіка. № 2, 2017. URL: http://www.economy.nayka.com.ua

6. Положення (стандарт) бухгалтерського обліку 1 «Загальні вимоги до фінансової звітності» : затверджене наказом Міністерства фінансів України від 07.02.2013 р. № 73, зі змінами та доповненнями URL: http://zakon5.rada.gov.ua/laws/show/336-13

7. Положення (стандарт) бухгалтерського обліку 15 «Дохід» : затверджене наказом Міністерства фінансів України від 29.11.1999 р. № 290, зі змінами та доповненнями. URL: http://zakon5.rada.gov.ua/laws/show/z60-99

\footnotetext{
Стаття надійшла

до редакції : 15.10 .2020 p.
}

8. Положення (стандарт) бухгалтерського обліку 16 «Витрати» : затверджене наказом Міністерства фінансів України від 31.12.1999 р. № 318, зі змінами та доповненнями URL: http://zakon5.rada.gov.ua/laws/show/z002700

\section{References}

1. Belozertsev, V.S., Kuznetsova, O. M. (2016). The statement of financial performance is its substance and significance in the context of national and international accounting standards. Global and national economic problems, 14, 902904.

2. Blonskaya, V. I. (2008). The strategy of income management of a trading company in the development of market relations. Scientific Bulletin of NLTU of Ukraine: Coll. scientific-technical wash, 18.6, 117-123.

3. Deriy, V. A. (2009). Expenses and incomes of enterprises in the accounting and control system: monograph. Ternopil: TNEU, "Economic Thought", 272.

4. Dobrunik, T. P. (2017). Modern issues of accounting for financial performance of commercial enterprises. Scientific Bulletin of Uzhhorod National University. Series: International Economic Relations and the World Economy, 13, 1, 95-99.

5. Knayz, S.V., Zalutsky, V.P. and Yavorskaya, N. P. (2017). Problems of accounting for income and expenses of commercial enterprises. Efficient economy. № 2, 2017. URL: $\mathrm{http} / / / \mathrm{www}$.economy.nayka.com.ua/op=1\&z=5425

6. Regulation (standard) of accounting 1 "General requirements for financial reporting": approved by the order of the Ministry of Finance of Ukraine dated 07.02.2013 № 73, with changes and additions. Retrieved from: http://zakon5.rada.gov.ua/laws / show / z0336-13

7. Regulation (standard) of accounting 15 "Income": approved by the order of the Ministry of Finance of Ukraine dated 29.11.1999 № 290, as amended. Retrieved from: http://zakon5.rada.gov.ua/laws/show/z0860-99

8. Regulation (standard) of accounting 16 "Expenses": approved by the order of the Ministry of Finance of Ukraine dated 31.12.1999 № 318, with changes and additions Retrieved from: http://zakon5.rada.gov.ua/laws/show/z0027 -00

Стаття прийнята

до друку: $28.12 .2020 \mathrm{p}$.

Бібліографічний опис для цитування :

Татар М. С. Облік і аудит доходів і витрат підприємств в умовах глобальних викликів / М. С. Татар, Г. М. Ванярха // Часопис економічних реформ. - 2020. - № 4 (40). - С. 67-75. 